Понимая, что специфика воинского труда влияет на реализацию различных функций внутри семьи военнослужащего, мы предложили респондентам несколько вопросов, касающихся семейных отношений.

Большинство опрошенных нами офицеров высказалось о желании иметь больше детей или иметь больше времени для общения со своими близкими, для реализации себя в роли родителя и воспитателя, воплощения себя в детях. Офицеры говорили об отсутствии условий для совместного с близкими проведения досуга и отдыха, о проблемах непонимания в семье и отсутствия поддержки со стороны близких.

Среди основных стрессов, которые испытывают семь опрошенных нами военнослужащих, были названы ситуации, связанные с неустроенностью быта, частыми переездами, отсутствием материальной стабильности в семьях, где супруга не работает и есть маленькие дети [3]. Семья военнослужащих действительно часто испытывает стрессы, связанные с причастностью к экстремальным условиям военной службы, и связанной с ней неустроенностью. При сменах места службы семья военнослужащих проходит несколько периодов социально-бытовой, психологической адаптации, что значительно снижает запасы личностного потенциала, который в других условиях мог бы тратиться на освоение новых видов деятельности, творчество и т.д.[4] Семья военнослужащего в связи с частыми переездами может оказаться замкнута в себе самой. При этом отсутствует возможность общения с родственниками, поддержки «Большой семьи» в важных семейных вопросах и ситуациях, что приводит к хроническому эмоциональному выгоранию и повышению внутрисемейной агрессии.
Проведя анализ результатов опроса военнослужащих и преподавателей МВОКУ, мы можем констатировать, что хотя военнослужащие по своему статусу не должны относиться к уязвимой части населения, в условиях современной военно-социальной среды они могут испытывать повышенное напряжение и дискомфорт, нуждаются в поддержке государства и общества, в том числе - в психологической поддержке.

Социальная ситуация развития личности современного российского офицера имеет некоторые негативные тенденции, по сравнению с периодом до политической перестройки в нашей стране. Эти тенденции выражаются в первую очередь в нарастании чувства отчужденности, переживания одиночества в своей профессиональной судьбе, трудном выстраивании смыслов своей службы, проблем в отношениях со своими близкими. Все эти особенности должны быть учтены в создаваемой системе повседневной и боевой работы с личным составом ВС РФ.

\section{Список научной литературы}

1.Ананьев Б. Г. Человек как предмет познания. Л., 1968 , с. $276-317$.

2.Блохин А.С. Содержание и развитие духовного мира офицера Вооруженных Сил современной России. Автореф. дис...канд. филос. наук. М.: Воен. ун-т. М. 2005.

3.Власова Т.В. Семейные отношения военнослужащих как объект психологического исследования // Психологические проблемы современной российской семьи. Материалы Всероссийской научной конференции. - Ч.1. - М., 2003. - C. 15-27.

4.Загорная И.Ю. Социально-психологическая адаптация семей военнослужащих к условиям гарнизонной жизни: Автореф. дис. ... канд. психол. наук. - М., 2007.

\title{
CHARACTERISTICS OF ETHNIC IDENTITY AMONG STUDENTS
}

DOI: 10.31618/ESU.2413-9335.2019.7.66.329

Jamila Safarova Elshad

Baku State University

Lecturer and doctorate, department of Social and Pedagogical psychology

\section{ABSTRACT}

The article discusses the features that affect the ethnic identity of students studying in the Azerbaijani and Russian languages.

The ideas related to the study of ethnic identity in the studies conducted in this direction, as well as the psychological mechanisms of this process in young people are analyzed.

Analysis of the results shows that students, studying in Azerbaijani language have indicators of the cognitive element of the ethnic identity higher than those of the students studying in Russian language. This means that the degree of self-awareness of their belonging to this ethnic group, opinions about the features of their own ethnic group are higher among students of the Azerbaijani Department. Analysis of the results also reveals the fact that students, studying in Azerbaijani language have indicators of the affective component of ethnic identity higher than students studying in Russian language. This indicates a positive attitude towards their ethnos as a whole, as well as the fact that young people have a pronounced emotional sense of belonging to their ethnic group, a high sensitivity towards their ethnos.

Keywords: ethnos, self awareness, studying process, ethnic self-awareness, identity, globalization 
In the context of globalization, one of the main features of the modern era is the revival of national selfconsciousness, ethnic identity and originality, strengthening the role of the ethnic factor in the social life of society. There is a growing interest in the native language, culture, traditions and history of their own people. However, this does not preclude the study of the ethnos of representatives of other peoples, especially in a polyethnic state.

In the study of ethnic characteristics, the focus is on cultural values, both material and spiritual, which involve the study of ethnic identity, ethno-cultural self.

Thus, a model of national identity can be proposed that takes into account the ratio of the general and the particular, i.e. in fact, it introduced the necessary multicultural values, not only by the "melting pot" method, but also by the rational ratio of the general and the individual.

The emotional expressiveness of ethnic selfconsciousness at present in the context of globalization is the desire of peoples to preserve their originality in new realities, their value attitude to culture, myths, rites, rituals, and a traditional way of life. All of the above emphasizes the importance of studying ethnic identity, ethno-cultural self.

The study of the ethnic identity of young students, as the most intimate part of self-consciousness, is of great relevance at the present stage of development.

It is at this age stage that the formation and development of an individual system of value orientations, the integration and differentiation of individual need-motivational characteristics, and ethnic self-awareness are taking place.

The age of young students is a significant stage in the development of national self-awareness, its strengthening and preservation. While studying at a higher educational institution, ethnic identity of a person at a young age develops, which contributes to the establishment of a system of clear knowledge about the world, about culture and clarifies the status of a young person in this world.

Obviously, it is possible to assume that the wellbeing of society depends on the characteristics of value orientations, national identity, ethnocultural self of modern youth, acting as a system of personal meanings and meanings, national sensory fabric in the structure of national self-awareness, and features of interethnic interaction. A stable active life position, moral convictions of young people in the context of global transformations largely determine the present and future of the country and people.

At the present stage of social development, the task of formation and formation of national identity has a significant place in the paradigms and practice of pedagogical activity. Currently, the pedagogical process does not pay due attention to issues of selfeducation, self-development, the formation of national self-awareness of youth, and also does not take into account the principles of multicultural education and multiculturalism as an essential factor in social development.

An analysis of the above provisions implies a special need for pedagogical aspects of managing the ethnic socialization of modern youth, the formation of ethnic concepts, the formation of an ethnocultural self. However, it should be noted that pedagogical management is carried out not only at the group level of an ethnocultural We, that is, values about the specificity, traditions, culture of an ethnos, but also at the level of individual ethnic identity, ethnocultural I.

The state policy of multiculturalism, the modern education system is actively forming positive interethnic attitudes. But this does not exclude certain facts of negative perception of a particular ethnic group in the youth, student environment.

The need to formulate issues of actualization and implementation of the ethnocultural self in the students' self-awareness generates significant confrontations in the pedagogical process, which push this psychological and pedagogical task into a list of extremely important problems that require proper dialectic resolution:

- between world determination, including Azerbaijani culture, towards unification and globalization and the extreme need to preserve ethnic values and identities;

- between the actualization of the ethnocultural Self and the formation of a tolerant attitude towards other ethnic groups;

- between the determination of the diffusion of ethnic identity and the need for the development of ethnic consciousness, ethnocultural self as a prerequisite for the formation of a clear civic position of modern youth.

The noted contradictions denote the problem: what conditions are necessary for actualizing national self-consciousness, ethnocultural $I$ as a natural development of ethnocultural We, the formation of a constructive life position of modern young people participating in the educational process.

Ethnicity - a material owner of cultural values and norms. A substantial revision of the role and significance of various ethnic groups and the impact of these processes on the self-consciousness of peoples becomes a definite system for the basis of ethnocultural education. This area of the educational process is most associated with the idea of reviving the various forms that have developed throughout history, types of ethnocultural activity.

It is necessary to identify the role of the ethnic significance of culture in explaining the meaning of ethno-cultural educational technical devices. The practical side of the educational process and the educational situation show that the formation of professional skills is closely related to the ethnoconfessional and professional way of life.

Thus, the problem of ethnic consciousness was very relevant both in the past and in the present. Psychological works and studies of consciousness and self-identity of a person occupy a significant place in the series of psychological literature.

Initially, the inclinations of ideas in the field of the psychology of peoples were considered by Hippocrates in the scientific treatise "On Air, Water, Terrain." The scientist believed that the peoples, as well as the "national spirit" are different from each other, since the climatic zones are different, the locations of the 
countries are different. [Hasanov N.N.2010].

The theory of ethnicity, which considers the problems of ethnic consciousness, was developed by ethnopsychologists. In 1860, scientists H. Steintal and M. Lazarus called the "psychology of peoples" a separate scientific branch from the rest. They analyzed the "folk spirit" as the similarity of people at the mental level who are representatives of a certain people, as well as their self-identity, the essence of which can be revealed through a comparative analysis of linguistic and cultural characteristics [Martynenko, S.A. 2004]. In order for the unity of ethnopsychological phenomena to form, the functioning of the basic products of the spiritual cultural community, namely language, moral features, mythology, is necessary. To explain such a "single spiritual community," W. Wundt proposed the concept of "spiritual community" (spiritual community). According to the author, the generation of derivatives of the national soul comes down to combining the energy of a large number of people who are in interactive relationships and living on the spiritual interaction of many who are attributed to these phenomena [Wundt V. 2004]. W. Wundt believes that should and has the opportunity to study the creative joint activities of the people. This is possible if you work in two directions: abstract and concretized. The first direction involves the study of the spirit of the people through those connections between individuals, believing that myths are the feelings of the people, foundations and customs are volitional and moral principles. The second direction involves the analysis of a particular ethnic group, using the results of the study according to the first option. Ethnic identity as a psychological phenomenon for a certain time was not the subject of study, but only met in the framework of such phenomena as "peoples psychology", "national character", "national spirit", etc. [Starovoitova G.V. Some methodological aspects, definitions of the subject area of ethnopsychology of the Autonomous Soviet Socialist Republic / G.V. Starovoitova, 1985, Shipilov, A.V. 2006].

Analyzing modern research results, within the framework of modern Azerbaijani psychology, issues of ethnic identity were reflected in the works of the following Azerbaijani authors: A.S. Bayramov, A.A. Alizade, B.G. Aliyev, K.R. Aliyeva and others. [Bayramov A.S, 2001, Alizade A.A., 2003, K.R. Aliyeva, 2002].

In modern scientific literature, the phenomenon of "Self-concept" is used mainly to designate and understand ethnic self-determination in foreign psychology. It was constructed within the framework of the theory of C. Rogers and is a set of perceptions that reflect the position of a person in various life situations, and arises on the basis of interaction with the social environment.

Starting from the second half of the 20th century, the issue of ethnic self-determination occupies a special place in studies of ethnic identity in the USA, supplementing, and most often replacing, the established concepts: "Self" (R. Burne, U James), "glass self" (Ch. Cooley), "self", "self", "identity" (E. Erickson, K. Jaspers), "Self-concept" (C. Rogers, M.
Rosenberg).

The concept of identity is comprehensively developed in the writings of the famous American scientist, social psychologist E. Erickson, who especially emphasized the adaptive nature of the individual's behavior, the main integrative characteristic of which is identity. The researcher defines this concept as a feeling of an individual's organic belonging to his history, a type of interpersonal interaction characteristic of a given era. The identity of a person supposes the harmony of ideas, images, values and actions belonging to her with the sociopsychological image of a person dominating in a given historical time, her acceptance of social being as her own [E. Erickson, 1976].

E. Erickson considered identity in two aspects. Firstly, it is the "I-identity", which includes two components: organic, i.e. given the physical appearance and natural inclinations of man, and individual, i.e. understanding of his own uniqueness, the desire for self-improvement and implementation of his own abilities and interests. Secondly, social identity, which consists of group and psychosocial. The group identity considered by E. Erickson is the involvement of the individual in various communities, supported by the subjective perception of internal unity with his social environment. Finally, psychosocial identity - this is what gives a person feels the importance of his being in the framework of this society (and from the point of view of society).

When it comes to the ethnic definition of identification, and more specifically self-identification, they talk about an individual comparing himself with any ethnic community, about a sense of belonging to this ethnic group based on certain ethnic characteristics. Comparison of these terms is made by mixing the concepts of a sense of belonging and a single " Self image " as an ethnic representative as a necessary condition for goal-setting.

Ethnic self-determination depends on complex, interdependent external and internal factors. Not only external orientational designations (ethnonym, language, culture, family, relatives, etc.), but also the inner self-awareness, well-being of a person determines these actions. A feeling of kinship is not the result of so much joint activity as the display of sensory relations with this community.

Ethnic identity is becoming the most important factor for ethnic groups to form and develop their social ties. Therefore, based on this, correlation with a large social (ethnic) community can be a fairly strong accelerator of mass behavior and political action. Consequently, the popularity of a certain group selfdetermination (in particular, ethnic) can be one of the factors predicting a possible trend in the political development of society [E. Erickson, 1976].

When an individual identifies himself with a particular ethnic group, he thereby includes such values, beliefs, ideas that characterize this community, as well as being unique and inimitable.

The basic psychological needs of a person determine ethnic identity, namely: 1) the need for protection and the need for security; 2) the need for 
belonging to a community, to a group; (according to E. Fromm, in a state of social crisis, a person is usually quite ready to exchange their newfound (or imposed) freedom for a sense of (even real) security and belonging to a group; 3) the need for originality, uniqueness, uniqueness of one's "I", confidence in oneself self, freedom from others, since the existence of a person as a person means his complete difference from others.

The listed basic needs of a person are usually contradictory, since the processes of identification and individualization are unified [Fromm, E, 1993]. Ethnic identity is a special sociocultural and sociopsychological phenomenon, as a result of which a person goes through a process of complex selfdetermination in the surrounding society in relation to many other ethnic groups. Ethnic self-determination is not only awareness and understanding, but also perception, emotional evaluation of one's involvement in an ethnic group.

Based on this, two important components are distinguished in the structure of ethnic identity cognitive and emotional-evaluative. The cognitive component includes ethnic awareness (certain specific knowledge and perceptions of the individual about ethnic groups - the history of their own and other ethnic groups, their traditions, as well as the existing differences between them), as well as ethnic selfidentification (the use of ethnic "labels" - ethnonyms). An emotional-evaluative component is an assessment of the qualities and traits of one's group, attitude to membership in it, and how important this membership is for a person.

\section{The hypothesis of the research}

The hypothesis of the research is that the ethnic self-consciousness of modern students (Azerbaijanis) is characterized by a certain intensity of ethnocultural self, ethnic identity and tolerance, the effective formation of which is carried out in educational activities.

\section{Research methods.}

- Scale questionnaire by O.L. Romanova for the study of ethnic identity

- J.Finney's method that determines the expression of ethnic identity

1.Participants and setting

The research has involved 200 students from various faculties of the Baku State University, of whom 100 people have been students of the second and third years of the Azerbaijani Department of the faculties of Social Sciences and Psychology, Philology, Applied Mathematics, and the other 100 are students of the second and third years of the Russian Department of the faculties of Social Sciences and Psychology, Philology, Applied Mathematics.

2.Scale questionnaire by O.L. Romanova for the study of ethnic identity

The first scale characterizes the sense of belonging to own group. Analysis of the results under the first scale shows that students of the Azerbaijani Department have indicators of a sense of belonging to their ethnic group higher than students of the Russian Department. (Fig.1.1)

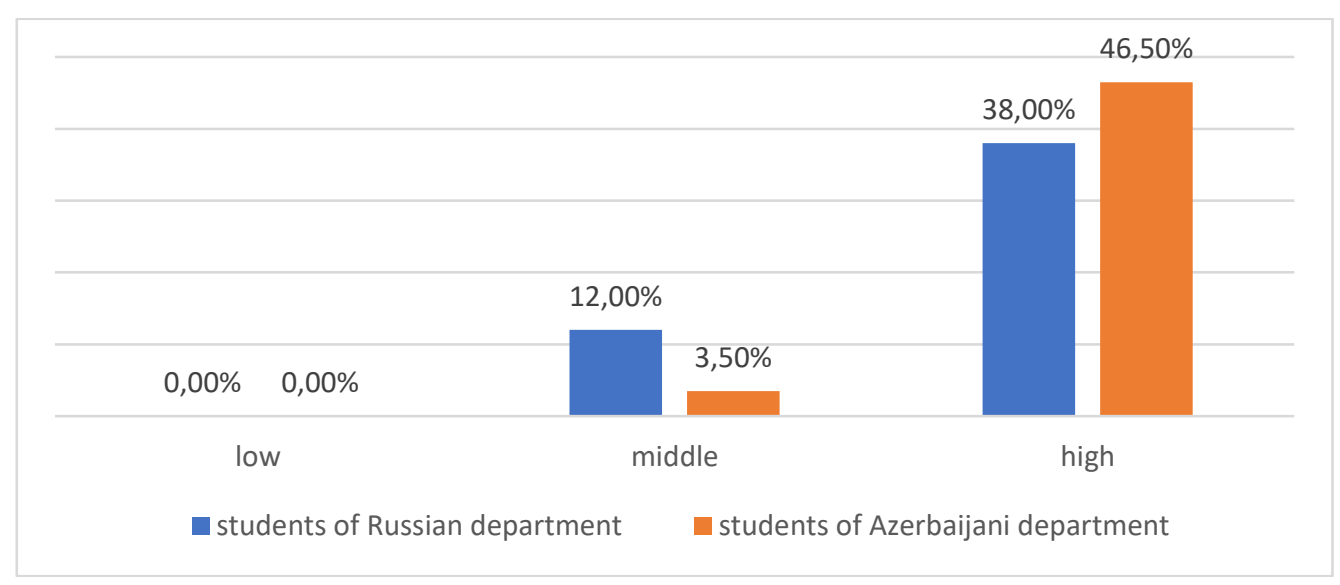

Fig.1.1 Results under the scale of 'a sense of belonging to own group'

The second scale characterizes the significance of ethnicity (Fig.1.2).

Analysis of the results shows that students of the Azerbaijani Department have higher indicators than students of the Russian Department. This indicates that ethnicity is very significant for students of the Azerbaijani Department. 


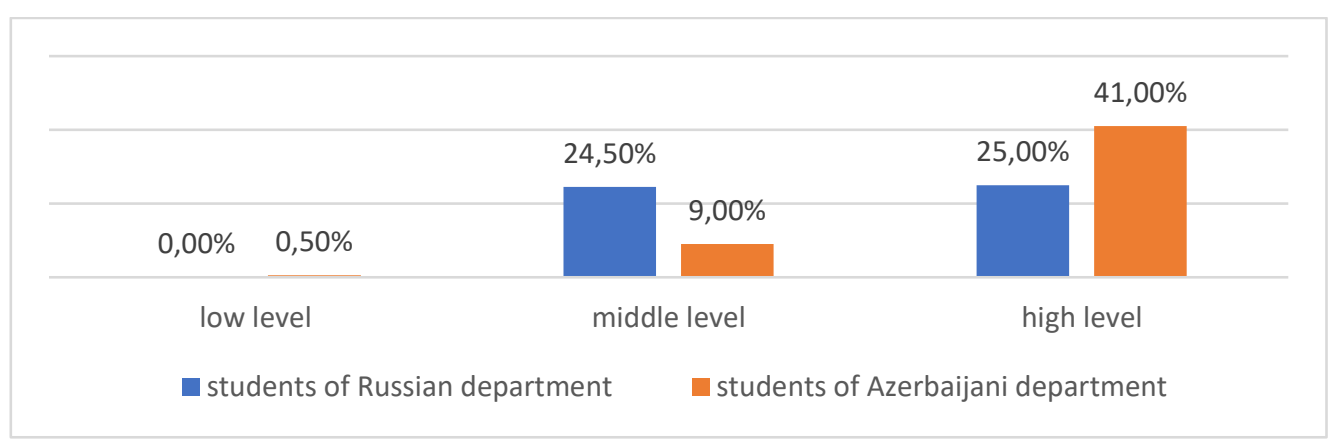

Fig.1.2 Results under the scale of 'significance of ethnicity'

The third scale defines the relationship of the ethnic environment, that is, the relationship between the majority and the minority (Fig.1.3). Analysis of the results has revealed that the students of the Azerbaijani Department have higher indicators than students of the
Russian Department. That is, students of the Azerbaijani Department are more inclined to believe that the ethnic majority should dominate and have certain advantages in society.

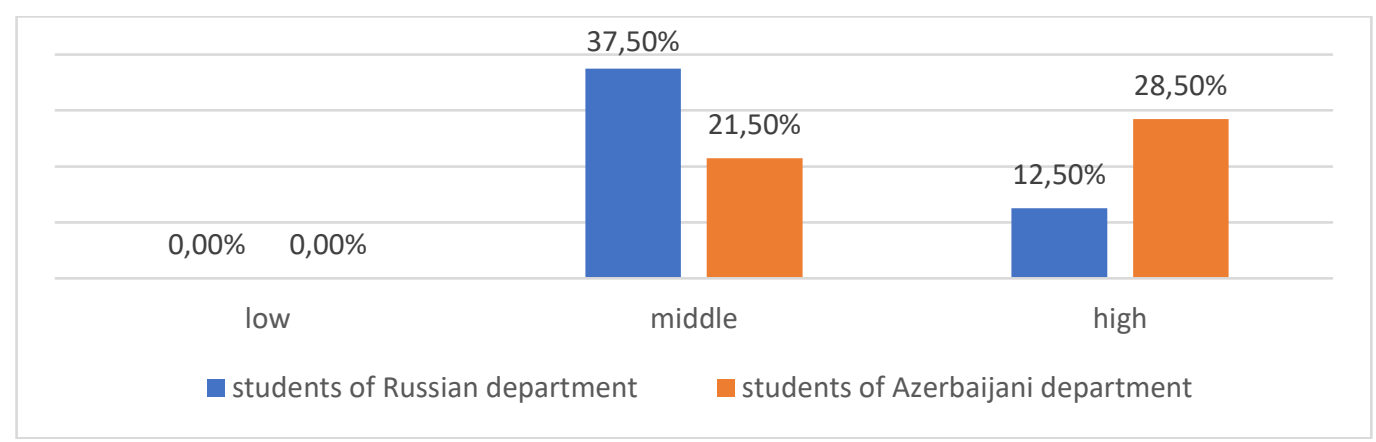

Fig.1.3 Results under the scale of 'the relationship of the ethnic majority and minority'

STATISTICAL INDICATORS BY THE METHOD OF "SCALE QUESTIONNAİRE BY O.L. ROMANOVA FOR THE STUDY OF ETHNIC IDENTITY"

\begin{tabular}{|c|c|c|c|c|}
\hline \multirow{2}{*}{\multicolumn{2}{|c|}{ Group }} & $\begin{array}{c}\text { 'a sense of belonging } \\
\text { to own group' }\end{array}$ & $\begin{array}{c}\text { significance of } \\
\text { ethnicity }\end{array}$ & $\begin{array}{c}\text { the relationship of the ethnic } \\
\text { majority and minority }\end{array}$ \\
\hline \multirow{4}{*}{$\begin{array}{c}\text { Russian } \\
(\mathrm{n}=100)\end{array}$} & Mean & 3.5600 & 3.2400 & 1.9400 \\
\cline { 2 - 5 } & Std. Deviation & 2.80087 & 3.33370 & 2.46109 \\
\cline { 2 - 5 } & Variance & 7.845 & 11.114 & 6.057 \\
\hline \multirow{3}{*}{$\begin{array}{c}\text { Azerbaijani } \\
(\mathrm{n}=100)\end{array}$} & Total & 356.00 & 324.00 & 194.00 \\
\cline { 2 - 5 } & Mean & 4.9800 & 5.6100 & 4.3300 \\
\cline { 2 - 5 } & Std. Deviation & 2.39098 & 2.74835 & 3.41729 \\
\hline
\end{tabular}

INDEPENDENT SAMPLES TEST OF "SCALE QUESTİONNAIRE BY O.L. ROMANOVA FOR THE STUDY OF ETHNIC IDENTITY"

\begin{tabular}{|c|c|c|c|c|c|c|c|}
\hline & & & & & & \multicolumn{2}{|c|}{$\begin{array}{c}95 \% \text { confidence } \\
\text { interval of the } \\
\text { difference }\end{array}$} \\
\cline { 3 - 8 } & $\mathrm{T}$ & $\mathrm{df}$ & $\begin{array}{c}\text { Sig. (2- } \\
\text { tailed) }\end{array}$ & $\begin{array}{c}\text { Mean } \\
\text { difference }\end{array}$ & $\begin{array}{c}\text { Std. Error } \\
\text { difference }\end{array}$ & \multicolumn{2}{c|}{$\begin{array}{c}\text { Lower } \\
\text { upper }\end{array}$} \\
\cline { 4 - 8 } $\begin{array}{c}\text { a sense of belonging to } \\
\text { own group' }\end{array}$ & -3.856 & 198 & .000 & -1.42000 & .36826 & -2.14622 & -.69378 \\
\cline { 2 - 8 } & -3.856 & 193.242 & .000 & -1.42000 & .36826 & -2.14633 & -.69367 \\
\hline $\begin{array}{c}\text { significance of } \\
\text { ethnicity' }\end{array}$ & -5.485 & 198 & .000 & -2.37000 & .43205 & -3.22202 & -1.51798 \\
\cline { 2 - 8 } & -5.485 & 191.051 & .000 & -2.37000 & .43205 & -3.22221 & -1.51779 \\
\hline $\begin{array}{c}\text { the relationship of the } \\
\text { ethnic majority and } \\
\text { minority }\end{array}$ & -5.675 & 198 & .000 & -2.39000 & .42113 & -3.22047 & -1.55953 \\
\cline { 2 - 8 } & -5.675 & 179.926 & .000 & -2.39000 & .42113 & -3.22098 & -1.55902 \\
\hline
\end{tabular}


Table 1.3

CORRELATIONS OF "SCALE QUESTIONNAİRE BY O.L. ROMANOVA FOR THE STUDY OF ETHNIC IDENTITY"

\begin{tabular}{|c|c|c|c|c|c|}
\hline \multirow{5}{*}{ Department } & Group & $\begin{array}{c}\text { a sense of } \\
\text { belonging to own } \\
\text { group }\end{array}$ & $\begin{array}{c}\text { significance of } \\
\text { ethnicity' }\end{array}$ & $\begin{array}{c}\text { the relationship of } \\
\text { the ethnic majority } \\
\text { and minority }\end{array}$ \\
\cline { 2 - 6 } & Pearson Correlation & 1 & $.264^{* *}$ & $.363^{* *}$ & $.374^{* *}$ \\
\cline { 2 - 6 } & Sig. (2-tailed) & & .000 & .000 & .000 \\
\hline \multicolumn{2}{|r|}{$\mathrm{N}$} & 200 & 200 & 200 & 200 \\
\hline
\end{tabular}

Statistical processing using the SPSS Method according to this methodology reveals the existence of dependence between the indicators of all three scales and the training departments (Azerbaijani and Russian). Significant differences have been revealed according to the t-test table.

3.Finney's method measuring the degree of intensity of ethnic identity.
The first component of the expression of ethnic identity is cognitive (Fig.2.1). Analysis of the results shows that students of the Azerbaijani Department have indicators of the cognitive element of the ethnic identity higher than those of the students of the Russian Department. This means that the degree of awareness of their belonging to this ethnic group, opinions about the features of their own ethnic group are higher among students of the Azerbaijani Department.

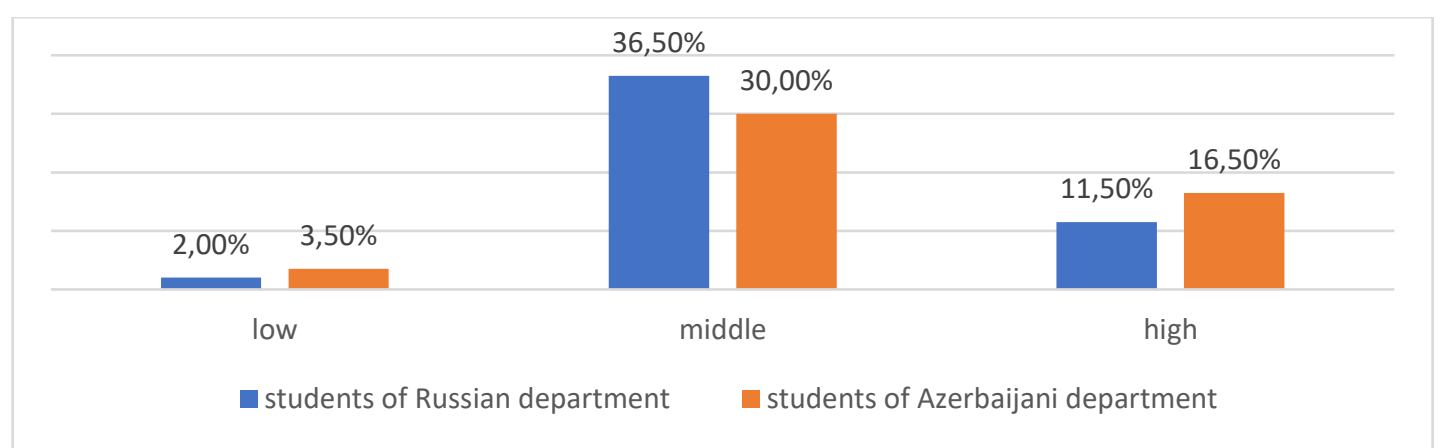

Fig.2.1 Indicators of the results under the cognitive component of ethnic identity expression

The second component of the expression of ethnic identity is affective (Fig.2.2). Analysis of the results reveals the fact that students of the Azerbaijani Department have indicators of the affective component of ethnic identity higher than students of the Russian
Department. This indicates a positive attitude towards their ethnos as a whole, as well as the fact that young people have a pronounced emotional sense of belonging to their ethnic group, a high sensitivity towards their ethnos.

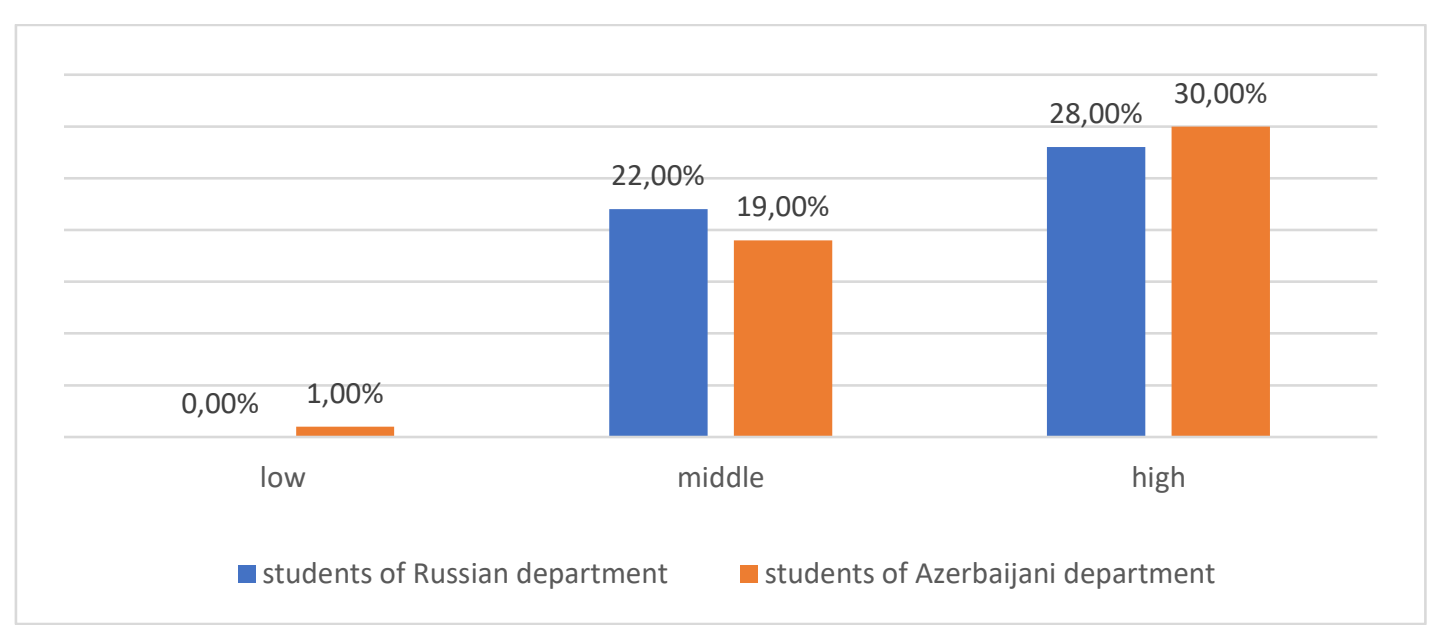

Fig.2.2 Indicators of the results under the affective component of ethnic identity

Statistical processing using the SPSS Method according to this methodology reveals the existence of dependence between the indicators of all three scales and the training departments (Azerbaijani and Russian). Significant differences have been revealed according to the t-test table. 
Table 2.1

STATISTICAL INDICATORS BY THE METHOD OF FINNEY'S METHOD MEASURING THE DEGREE OF INTENSITY OF ETHNIC IDENTITY

\begin{tabular}{|c|c|c|c|}
\hline \multicolumn{2}{|c|}{ Group } & cognitive component & affective component \\
\hline \multirow{4}{*}{ Russian d. } & Mean & 8.1100 & 14.8200 \\
\cline { 2 - 4 } & Std. Deviation & 2.81014 & 3.97055 \\
\cline { 2 - 4 } & Variance & 7.897 & 15.765 \\
\cline { 2 - 4 } & Total & 811.00 & 1482.00 \\
\hline \multirow{3}{*}{ Azerbaijani d. } & Mean & 9.5000 & 15.9900 \\
\cline { 2 - 4 } & Std. Deviation & 2.91114 & 4.64605 \\
\cline { 2 - 4 } & Variance & 8.475 & 21.586 \\
\cline { 2 - 4 } & Total & 950.00 & 1599.00 \\
\hline
\end{tabular}

Table 2.2

INDEPENDENT SAMPLE TEST OF FINNEY'S METHOD MEASURING THE DEGREE OF INTENSITY OF ETHNIC IDENTITY

\begin{tabular}{|c|c|c|c|c|c|c|c|}
\hline & \multirow{2}{*}{$\mathrm{T}$} & $\mathrm{df}$ & \multirow{2}{*}{$\begin{array}{c}\text { Sig. (2- } \\
\text { tailed) }\end{array}$} & $\begin{array}{c}\text { Mean } \\
\text { Difference }\end{array}$ & \multirow{2}{*}{$\begin{array}{c}\text { Std. Error } \\
\text { Difference }\end{array}$} & \multicolumn{2}{|c|}{$\begin{array}{c}\text { Confidence Interval of the } \\
\text { Difference }\end{array}$} \\
\cline { 7 - 9 } & & & & & Lower & Upper \\
\hline $\begin{array}{c}\text { Cognitive } \\
\text { component }\end{array}$ & -3.435 & 198 & .001 & -1.39000 & .40462 & -2.18791 & -.59209 \\
\cline { 2 - 8 } & -3.435 & 197.754 & .001 & -1.39000 & .40462 & -2.18792 & -.59208 \\
\hline $\begin{array}{c}\text { Affective } \\
\text { component }\end{array}$ & -2.578 & 198 & .011 & -1.56000 & .60522 & -2.75351 & -.36649 \\
\cline { 2 - 8 } & -2.578 & 194.236 & .011 & -1.56000 & .60522 & -2.75365 & -.36635 \\
\hline
\end{tabular}

CORRELATIONS OF FINNEY'S METHOD MEASURING THE DEGREE OF

Table 2.3 INTENSITY OF ETHNIC IDENTITY

\begin{tabular}{|l|c|c|c|c|}
\hline & & Group & $\begin{array}{c}\text { Cognitive } \\
\text { component }\end{array}$ & Affective component \\
\hline \multirow{3}{*}{ Group } & Pearson Correlation & 1 & $.237^{* *}$ & $.180^{*}$ \\
\cline { 2 - 5 } & Sig. (2-tailed) & & .001 & .011 \\
\cline { 2 - 5 } & $\mathrm{N}$ & 200 & 200 & 200 \\
\hline \multicolumn{2}{|c|}{ *. Correlation is significant at the 0.05 level (2-tailed.) } & & \\
\hline
\end{tabular}

Analysis of the tables and figures according to the second methodology shows that students of the Azerbaijani Department have indicators of cognitive and affective components of ethnic identity higher than students of the Russian Department. In our opinion, knowledge and ideas about the characteristics of their ethnic group among students in the Azerbaijani Department are more stable and settled, and also they are more emotionally attached to their own ethnic group and culture.

\section{Discussions of results}

The results of the research have confirmed that the ethnic self-consciousness of modern students (Azerbaijanis) is characterized by a certain expression of ethnocultural self, ethnic identity and tolerance, the effective formation of which is carried out in educational activities.

The second language and intercultural enrichment are essential factors of ethnic socialization and therefore, the language of instruction has a significant impact on the indicators of tolerance and ethnic identity in student groups. According to these provisions, we have revealed a higher level of tolerance in the Russian Department and a high degree of expression of ethnic identity among students of the Azerbaijani Department.

A significant factor in the formation of ethnic identity is the age factor and level of education. Developing in direction of personal identity and actualizing, ethnic identity has an age-related dynamics of development.

In our opinion, the practical significance of the obtained results is of great importance, since it reveals a new promising line of research in the field of educational and ethnic psychology.

Young people may have an increased interest in the problems of social interaction and development of ethnic identity in the context of learning activities.

Ethnocultural self, ethnic identity shows the direction, value orientations of the behaviour of young people and helps to anticipate the development of positive or negative ethnic phenomena in society. More attention should be paid in pedagogical activity to the 
formation and development of ethnic selfconsciousness and ethno-cultural self, taking into account the principles of polycultural education.

\section{References:}

1.Bayramov Ә.S. Etnik psixologiya. Bak1: Renessans, 2001, 374s.

2.ĐliyevR.İ. Şəxsiyyət və onun formalaşmasının etnopsixoloji əsasları.Bak1: Araz, 2000, 196s.

3. ӘlizadəӘ.Ә.

Azərbaycanetnopsixolgiyasınagiriş : problemlər, ilkinaraş- dırmalar. Bakı: Renessans, 2003, 260s.

4.Алиева К.Р. Творчество как фактор развития личности: Автореф. дис. ... докт. фил. по психол., Баку, 2002, 24c.

5.Вундт В. Психология народов Текст. / В. Вундт; М.: Издательство ЭКСМО; СПб.: Terra Fantastica, 2002, 864 c.

6.Гасанов Н. Н. О культуре межнационального общения / Н. Н. Гасанов // Социальнополитический журнал. 2010, № 3, с. 232-237

7.Мартыненко, С.А. Педагогические средства повышения квалификации преподавателей к реализации поликультурного образования: на примере повышения квалификации преподавателей иностранных языков. Дис. ... канд. пед. наук, Ростов-на-Дону, 2004, 204 с.

8.Старовойтова Г.В. Некоторые методические аспекты, определения предметной области этнопсихологии АССР / Г.В. Старовойтова // Социальная психология и общественная практика: сборник статей / отв. ред. Е.В. Шорохова, В.П. Левкович. М.: Наука, 1985, 233 с.

9.Стефаненко Т.Г. Этнопсихология: учебн. Пособие / М.: 2002, 368 с.
10.Столин, В.В. Самосознание личности. М.: Изд-во МГУ, 1983, .213с.

11.Фрейд, 3. Я и Оно / Труды разных лет. Тбилиси : Мерани, 1991, с.351-369.

12.Фромм, Э. Психоанализ и этика . / Э. Фромм; М.: Республика, 1993, 415 с.

13.Шипилов, А.В. «Свои», «чужие», и другие. От античности до современности. / А.В. Шипилов // Социологические исследования. 2006, №5, с. 1824

14.Шпет Г.Г. Введение в этническую психологию / Г.Г. Шпет. - Спб., Питер, 1996, 154 с.

15.Эриксон Э. Идентичность: юность и кризис / пер. с англ. - М.: Прогресс, 1996. -344c.

16.Barret, (1996). English children's acquisition of a European identity. In: Breakwell, G. \& Lyons, E (Eds) changing European identities: Socialpsychological Analyses of Social Change. Oxford Pergamon Press. - 454 p.

17.Baumeister, R.F. Public self and private self / R.F Baumeister. - NY, Springer-Verlag, 1986.

18.Christian, D., Two-Way Immersion Education: Students Learning through Two Languages. The Modern Language Journal, Vol. 80, No. 1 (Spring, 1996)

19.Phinney J.S. Ethnic identity in adolescents and adults: Review of research //Psychological Bulletin. 1990. Vol.108 (3). P.499-514.

20.Tajfel H. Aspects of national and ethnic ioyalty // Social science information. Oxford-Edinburg, 1971. P. 7-24.

21.Tiedt, P.L., Tiedt, I.M. Multicultural teaching. Boston: MA Allyn and Bacon, 1999. - 188 p. 